\title{
Periprostetik eklem enfeksiyonu ameliyat öncesi tanı yöntemleri
}

\section{Preoperative diagnosis of periprosthetic joint infection}

\author{
Vahit Emre Özden, Burak Beksaç \\ Acıbadem Üniversitesi Tıp Fakültesi, Ortopedi ve Travmatoloji Anabilim Dalı; \\ Acıbadem Maslak Hastanesi Ortopedi ve Travmatoloji Bölümü, İstanbul
}

\begin{abstract}
Artan artroplasti uygulamaları ile birlikte enfekte artroplasti olgu sayısının artması, tanıya yönelik daha sistematik bir yaklaşımı gerektirmiştir. Mevcut birçok teste rağmen, periprostetik eklem enfeksiyonu (PEE) kesin tanısını koymak sorun olmaya devam etmektedir. Enfeksiyon açısından hastaya ait risk faktörlerini sorgulayacak kapsamlı öykü ve fizik muayene, eritrosit sedimentasyon hızı ve serum C-reaktif protein ve uygun radyografiler, tanıya yönelik ilk basamak yaklaşımlar olmalıdır. Il gili eklem ponksiyonu ve sinoviyal sıvı aspirasyonu, PEE tanısında yüksek değere sahiptir. Alınan sıvıda, eklem sıvısı lökosit sayımı, polimorfonükleer hücre oranı ve mikrobiyolojik (aerobik anaerobik) kültüre bakılmalıdır. Kültür için alınan örnek, pediatrik kan kültürü şişeleri içerisine hemen ekilmelidir. Son dönemde yapılan çalışmalarda, eklem sıvısındaki bazı biyolojik moleküllerin, sistemik inflamatuvar hastalıklara ve antibiyotik kullanımına rağmen, yüksek tanı değerlerine sahip oldukları gösterilmiştir. Tanı sırasında karşılaşılan zorluğun, sinoviyal sıvıdaki bu biyolojik moleküllerin miktarının değerlendirilmesiyle çözülebileceği bildirilmiştir.
\end{abstract}

Özet olarak, ameliyat öncesi PEE tanısı ve etkenin belirlenmesi, tedavinin planlaması ve başarısı için anahtardır. Yakın zamana kadar enfeksiyona spesifik bir tanı testi yok iken, yeni çalışmalar enfeksiyon spesifik moleküllerin eşik değerlerini bildirmeye başlamıştır. Yakın bir gelecekte bu testlerin ticari olarak yaygın kullanımıyla, ameliyat öncesi PEE tanısının çok daha kolaylaşacağı düşünülmektedir.

Anahtar sözcükler: periprostetik eklem enfeksiyonu; tanı; eklem sıvısı aspirasyonu; artroplasti
More infected cases periprosthetic joint infections (PJI) are seen with increasing number of arthroplasty procedures. Despite many tests are available, diagnosis of PJI remains a challenge and a more systematic approach is required. A comprehensive medical history including risk factors for infection, physical examination, erythrocyte sedimentation rate and serum C-reactive protein levels, and also appropriate radiographs are the first line screening tests. Joint aspiration has a high value in the diagnosis of PJI. Aspirates which should be immediately transferred into pediatric blood culture bottles for cultures, should also be sent for synovial leukocyte count and polymorphonuclear percentage. Recently, it has been shown that some biomarkers in the synovial fluid exhibit a higher accuracy in diagnosis of PJI despite patients with the systemic inflammatory diseases and those receiving antibiotic treatment. These synovial fluid biomarkers are expected to overcome the challenges in diagnosis of PJI.

In summary, the diagnosis of PJI is the key for planning and the success of the treatment. While there is no specific diagnostic test recently, studies have begun to inform threshold levels of the synovial fluid biomarkers. In the near future a preoperative diagnosis of PJI would be easier with the widespread commercial use of these tests.

Key words: periprosthetic joint infection; diagnosis; synovial fluid aspiration; arthroplasty

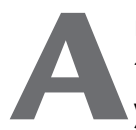

rtan artroplasti uygulamaları ile birlikte enfekte artroplasti olgu sayısının artması ${ }^{[1,2]}$, tanıya yönelik daha sistematik bir yaklaşımı gerektirmiştir. Ancak, aktif enfeksiyonun kesin tanısını koyacak, kabul görmüş tek bir inceleme yöntemi mevcut değildir. Bu amaçla, 2011 yılında Amerikan Kas-i̇skelet Enfeksiyon Derneği (Musculoskeletal Infection Society MSIS) tarafindan protez etrafi (periprostetik) enfeksiyonu (PEE) tanımlaması yapılmıştır. ${ }^{[3]}$ Tanı sırasında altın standart olmaması nedeni ile, Amerikan Ulusal Ortopedi Derneği (AAOS) tarafindan 2010 yılında bir PEE tanı kılavuzu düzenlenmiştir. ${ }^{[4]} 2013$ yılında, konuda tecrübeli uzmanlarında katılımı ile, uluslararası periprostetik eklem enfeksiyonları ortak görüş toplantısı yapılmış ve enfeksiyonun tanı, tedavi ve önlenmesi konusunda ortak görüşler sunulmuştur. ${ }^{\left[{ }^{[]}\right.} \mathrm{Bu}$ yazıda, ameliyat öncesi dönemde PEE tanı yöntemleri incelenmiştir.

- İletişim adresi: Op. Dr. Vahit Emre Özden, Acıbadem Üniversitesi, Acıbadem Maslak Hastanesi, Ortopedi ve Travmatoloji Bölümü Büyükdere Cad. No: 40. Maslak, İstanbul Tel: 0212 - 3044414 e-posta: vahitemre@gmail.com

- Geliș tarihi: 1 Mart 2016 Kabul tarihi: 1 Mart 2016 


\section{HASTA HIKAYESI (RISK FAKTÖRLERI)}

Hastada enfeksiyon gelişimi açısından var olan riskleri bilmek, tanıya yönelik yapılacak tetkiklerin daha doğru yorumlanmasını sağlar. Çoklu veya yüksek risk faktörü olan hastalarda, tanı amaçlı tetkiklerin derinleştirilmesi veya tekrarı gerekir.

\section{Kanıtlanmış Risk Faktörleri}

- Yüzeyel ameliyat yeri enfeksiyonu öyküsü. ${ }^{[6,7]}$

- Öncesi eklem enfeksiyon öyküsü.. ${ }^{[8]}$

- Obezite. [9-12]

- İmmün yetmezlik durumları (romatoid artrit ${ }^{[8]}$, diyabet $^{[12]}$, immünsupresif tedavi)

\section{Potansiyel Risk Faktörleri}

- Hematom oluşumu. ${ }^{[6,13,14]}$

- Gecikmiş yara iyileşmesi. ${ }^{6,14]}$

- Uzun süren yara yeri akıntısı. ${ }^{[6,14]}$

Diğer potansiyel risk faktörleri yüksek kalitede çaIışmalarda ispatlanmamış olsa da, AAOS kılavuzu komitesi tarafindan ortak görüş olarak, risk faktörü kapsamında değerlendirilmiştir. Buna göre; son bir yıl içerisinde gelişen bakteriyemil ${ }^{[15]}$, metakron protez eklem enfeksiyonu[16], deri rahatsızlıkları (psöriasis, lenfödem, kronik selülit, kronik venöz staz), iv ilaç kullanımı, son üç yıl içerisinde MRSA enfeksiyonu veya kolonizasyonu sayılabilir. Sigara kullanımı ${ }^{[17]}$, önceki açık cerrahi girişim ${ }^{[18]}$, uzamış hastanede yatış süresi, kan transfüzyonu ve medikal morbiditeler ${ }^{[19]}$, kanıta dayalı yeterli çalışma olmasa da PEE için risk faktörleri olarak sunulmuştur.

\section{GÖRÜNTÜLEME YÖNTEMLERi}

PEE'den şüphelenilen her hasta için direkt radyografi istenmelidir. Genellikle normal görünüm elde edilse de, erken dönem gevşeme ve osteoliz görüntüsü, diğer tetkikler öncesi enfeksiyon tanı olasılığını arttırır. [4]

Nükleer görüntüleme tetkiklerinden lökosit işaretli çalışmalar, özellikle indium-111 (In-111) enfeksiyonun olmadığını göstermek amaçlı kullanılabilir. Hatta, technetium-99 (Tc-99) kemik taramasının In-111 ile beraber kullanımının tanıda daha etkin olduğu belirtilmiştir. Gallium-67 ile yapılan görüntüleme, yüksek özgünlük gösterse de düşük duyarlılığa sahiptir. Florodeoksiglukoz pozitif emisyon tomografisinin (FDG-PET), enfeksiyon tanısını dışlamada etkili olduğu gösterilmiştir. ${ }^{[20]}$ Nükleer tetkikler, sonuçlarında çeşitlilik göstermesi, zaman ve maliyeti açısından avantajlı olmamaları nedeni ile, enfeksiyon ön tanısı ile revizyon planlanan hastada kesin tanı için birinci planda düşünülmemelidir. Ancak, subklinik seyreden enfeksiyonda tanıya yardımcı olabilecek bir seçenek olarak düşünülmelidir.

Protez etrafi enfeksiyonu uluslararası konsensusunun ileri görüntüleme konusundaki güçlü tavsiyesi; manyetik rezonans (MR) görüntüleme, bilgisayarlı tomografi (BT) ve nükleer görüntüleme yöntemlerinin enfeksiyon tanısında rolü olmadığı, fakat yetersizlik ve ağrıya yol açabilecek diğer nedenlerin tespiti amaçlı kullanılabileceği yönündedir. ${ }^{[5]}$

\section{SEROLOJiK TANI YÖNTEMLERi}

ESR (eritrosit sedimentasyon hızı) ve serum CRP (C-reaktif protein) laboratuvar testleri, PEE için ilk tarama testleri olarak kabul görmüştür. Bunlar, protez ameliyatı sonrası ağrı şikayeti olan veya revizyon artroplastisi planlanan hastalarda alınması gereken ilk testlerdir. Bu testler, ekonomik, kolay uygulanabilir ve ulaşılabilir yöntemlerdir. ${ }^{[21,22]}$ ESR ve CRP testlerinin herhangi birinin tek kullanılması, sırası ile \%94,5 ve \%94,3 duyarlılık oranlarına sahipken, birlikte kullanımı duyarlılık oranını \%97,5'e çıkarmaktadır. [23]

Serum lökosit ve nötrofil sayısının (sola kayma) tanısal değeri arttırmadığı gösterilmiştir. ${ }^{[24]}$

Serum interlökin-6 (IL-6) seviyesinin, enfeksiyon tanısında kullanıldığında, 10 pg/mL üzerindeki değerde duyarlılığının \%100, özgünlüğünün ise \%95 olduğu belirtilmiştir. ${ }^{[25]}$ Bir başka çalışmada ise, $12 \mathrm{pg} / \mathrm{ml}$ değerin üzerinde duyarlılığın \%95, özgünlüğün ise \%87 olduğu belirtilmiştir. ${ }^{[26]}$ Fakat, maliyet ve erişebilirliği açısından kullanışlı değildir.

Klinik çalışmalar, enfeksiyon varlığında iki testin çok nadir normal olduğunu göstermiştir. İki yüz otuz beş revizyon kalça artroplasti olgusu içeren çalışmalarında, Schinsky ve arkadaşları, normal ESR ve CRP değerli hastalarda enfeksiyon saptamamışlardır. ${ }^{[22] ~ S p a n g e h l ~}$ ve arkadaşları ise, CRP ile ESR'nin birlikte normal değerlerinin, enfeksiyon olmadığı yönünde tahmini yükselttiği ve güvenilirliğini arttırdığını göstermişlerdir. [24] Inflamatuvar artritin, ESR ve CRP değerlerini etkilediği ve sonucun güvenirliliğini azalttığı düşünülmektedir. Ancak, 60 inflamatuvar artrit hastasının dahil olduğu 871 artroplasti vakası içeren bir çalışmada, ESR ve CRP değerlerinin inflamatuvar ve non-inflamatuvar artritte benzer eşik değerleri ve test sonuçları gösterdiği ve bunun enfeksiyon tanısı için değerli olduğu gösterilmiştir. ${ }^{[27]}$

ESR ve CRP, PEE için mükemmel bir tarama testi olup, AAOS tarafindan oluşturulan kılavuzda kuvvetle önerilmiştir. Enfeksiyon şüphelenilen veya herhangi bir revizyon artroplastisi öncesi mutlaka bakılmalıdır. ${ }^{[28]}$ 
Tablo 1. Periprostetik eklem enfeksiyon tanısında lökosit sayısı ve eşik değerleri[ ${ }^{38]}$

\begin{tabular}{|c|c|c|c|c|c|c|c|}
\hline & Eklem & $\begin{array}{l}\text { Vaka } \\
\text { sayısı }\end{array}$ & $\begin{array}{c}\text { Eşik değeri } \\
\text { (Lökosit/ } \mu \mathrm{L})\end{array}$ & $\begin{array}{c}\text { Duyarlılık } \\
\text { (sensitivite) }\end{array}$ & $\begin{array}{l}\text { Özgünlük } \\
\text { (spesifite) }\end{array}$ & $\begin{array}{c}\text { Tahmini pozitif } \\
\text { değer (PPV) }\end{array}$ & $\begin{array}{c}\text { Tahmini negatif } \\
\text { değer (NPV) }\end{array}$ \\
\hline Della Valle ve ark. ${ }^{[21]}$ & Diz & 105 & $>3000$ & 1,0 & 0,98 & 0,98 & 1,0 \\
\hline Trampuz ve ark. ${ }^{[29]}$ & Diz & 133 & $>1700$ & 0,94 & 0,88 & 0,73 & 0,98 \\
\hline Ghanem ve ark. ${ }^{[23]}$ & Diz & 429 & $>1100$ & 0,91 & 0,88 & 0,87 & 0,91 \\
\hline Spangehl ve ark. ${ }^{[24]}$ & Kalça & 202 & $>50000$ & 0,36 & 0,99 & 0,91 & 0,90 \\
\hline Schinsky ve ark. ${ }^{[22]}$ & Kalça & 201 & $>4200$ & 0,84 & 0,93 & 0,81 & 0,93 \\
\hline
\end{tabular}

Tablo 2. Akut ve kronik enfeksiyon eklem sivisı ve serum değerleri

\begin{tabular}{lccc}
\hline & $\begin{array}{c}\text { Eklem lökosit } \\
(\text { hücre } / \mu \mathrm{L})\end{array}$ & $\begin{array}{c}\text { Eklem } \\
\% \mathrm{PMN}\end{array}$ & $\begin{array}{c}\text { Serum CRP } \\
(\mathrm{mg} / \mathrm{L})\end{array}$ \\
\hline Erken (<6 hafta $)$ & 10.000 & 90 & 100 \\
Geç (>3 ay) & $\begin{array}{c}3000 \\
(1500-4000)\end{array}$ & 80 & 10
\end{tabular}

\section{SINOVIYAL SIVI ANALIZi}

Eklem sinoviyal sıvı aspirasyonu, PEE tanısında yüksek değere sahiptir. Alınan sıvıda, eklem sıvısı lökosit sayımı ve hücre tipi (polimorfonükleer hücre) oranına, mikrobiyolojik (aerobik - anaerobik) kültüre bakılmalıdır. ${ }^{[28]}$ Kültür için alınan örnek, sıvı pediatrik kan kültürü şişeleri içerisine hemen ekilmelidir.

Amerikan Ulusal Ortopedi Derneği (AAOS) 2010 yılı kılavuzuna göre, enfeksiyon tanısı için diz eklem sıvisı aspirasyonu, anormal CRP ve/veya ESR değerleri durumunda önerilir. Aspirasyonun tekrarı, üremenin olmadığı durumlarda, ilk kültür ile enfeksiyon olasılığı arasında çelişki bulunuyorsa önerilir.

Kalça eklem aspirasyonu, AAOS 2010 yılı kılavuzuna göre, yüksek risk taşıyan hasta grubunda, CRP veya ESR'nin yüksek olduğu durumlarda önerilir. Hasta, enfeksiyon açısından yüksek risk grubunda değil ise, CRP ve ESR'nin beraber yüksek olduğu durumlarda aspirasyon önerilir. Revizyon ameliyatı planlanan hastalara, yüksek risk grubunda olsun veya olmasın, CRP ve ESR değerleri normal ise ameliyat öncesi kalça aspirasyonu önerilmez. Revizyon ameliyatı planlanmayan düşük riskli hastalarda, CRP veya ESR'nin yüksek olması durumunda, enfeksiyon üç ay içerisinde tekrar değerlendirilmelidir. Revizyon ameliyatı planlanan düşük riskli hasta grubunda ise, ameliyat sırasında eklem SIVı aspirasyonu veya doku örneklemesi ile kesitlerin incelenmesi (frozen section) önerilir. ${ }^{[28]}$
Eklem içinden alınan örnekleme için, en az iki hafta önceden antibiyotik alımının kesilmesi gereklidir. Bu süre içerisinde, antibiyotik tedavisi almış hasta grubunda yalancı-negatif kültür sonucu oranları yüksek çıkabilir. ${ }^{[29]}$

Sinoviyal sıvıda artmış lökosit sayısı, PEE lehine bir bulgudur. Sinoviyal sıvı lökosit sayısı, birçok çalışmada PEE tanısı için mükemmel duyarlılık (sensitivite) ve özgünlük (spesifisite) değerleri göstermiştir (Tablo 1). Çalışmalarda, hücre sayımında farklılaşmaya bakıldığında, polimorfonükleer hücre (PMN) oranı \%65 (aralık, \%64-80) üzeri yüksek oranda enfeksiyonu işaret eder.[21,22,24,29] Akut ve kronik enfeksiyon ayrı$\mathrm{m}$ için, uluslararası periprostetik eklem enfeksiyonu konsensusunun güçlü görüşü ise, ameliyattan sonra en az altı hafta sonrasında alınan örnekte, lökosit $>3000$ hücre/ $\mu \mathrm{L}$ ve $\mathrm{PMN}$ hücre $>\% 80$ olarak belirlenmiştir (Tablo 2). ${ }^{[5]}$

Aspirasyon sıvısı kültürünün, diz protezi PEE tanısında yüksek özgünlüğe $(0,93-0,98)$ sahip olsa da, duyarlılığı $(0,78-0,80)$ daha düşüktür. Dolayısı ile, bu test PEE olmadığını göstermekten ziyade, varlığını araştırmada kullanılmalıdır. ${ }^{[21,30]}$ Benzer şekilde, kalça aspirasyonu kültürü, yüksek pozitif olabilirlik değeri (pozitif prediktif değer: 9,8) ile PEE tanısı için kullanılsa da, düşük negatif olabilirlik değeri (negatif prediktif değer: 0,33 ) ile enfeksiyonun olmadığını aynı güvenirlikte kanitlayamaz. ${ }^{[31-33]}$

Sinoviyal sıvıda lökosit esteraz seviyesi, rutinde idrar tahlilinde kullanılan reaktif lökosit esteraz şeritleri ile ölçülerek, eklem enfeksiyonu tanısında denenmiş ve etkili bulunmuştur. ${ }^{[34,35]}$ Fakat, enfeksiyon tanısında daha yüksek kesinlikte tanının, eklem sıvısı $\alpha$-defensin seviyesi ile sağlandığı bildirilmiştir. ${ }^{[36]}$

Son dönemde yapılan bir çalışmada ise, Deirmengian ve Parvizi tarafindan, eklem sıvısındaki bazı biyolojik moleküllerin ( $\alpha$-defensin, 1-3 nötrofil elastaz 2, 
bakterisidal/geçirgenlik arttırıcı protein, nötrofil jelatinaz bağlı lipokalin, ve laktoferrin), sistemik inflamatuvar hastalıklara ve antibiyotik kullanımına rağmen yüksek tanı değerlerine sahip oldukları gösterilmiştir. Tanı sırasında karşılaşılan zorluğun, sıvıdaki bu biyolojik moleküllerin eşik değerleri yardımı ile çözülebileceği bildirilmiştir. ${ }^{[37]}$

Özet olarak, ameliyat öncesi PEE tanısı ve etkenin belirlenmesi, tedavinin planlaması ve başarısı için anahtardır. Yakın zamana kadar enfeksiyona spesifik bir tanı testi yok iken, yeni çalışmalar, enfeksiyon spesifik moleküllerin eşik değerlerini bildirmeye başlamıştır. $^{[38]}$ Yakın bir gelecekte bu testlerin ticari olarak yaygın kullanımıyla, ameliyat öncesi PEE tanısı çok daha kolaylaşacaktır.

\section{KAYNAKLAR}

1. Kurtz SM, Ong KL, Schmier J, Mowat F, Saleh K, Dybvik E, Kärrholm J, Garellick G, Havelin LI, Furnes O, Malchau H, Lau E. Future clinical and economic impact of revision total hip and knee arthroplasty. J Bone Joint Surg Am 2007;89 Suppl 3:144-51.

2. Kurtz SM, Lau E, Schmier J, Ong KL, Zhao K, Parvizi J. Infection burden for hip and knee arthroplasty in the United States. J Arthroplasty 2008;23(7):984-91. Crossref

3. Parvizi J1, Zmistowski B, Berbari EF, Bauer TW, Springer BD, Della Valle CJ, Garvin KL, Mont MA, Wongworawat MD, Zalavras CG. New definition for periprosthetic joint infection: from the Workgroup of the Musculoskeletal Infection Society. 2011;469(11):2992-4. Crossref

4. AAOS, American Academy of Orthopaedic Surgeons. Guideline on the Diagnosis of Periprosthetic Joint Infections of the Hip and Knee; 2010. http://www.aaos.org/ CustomTemplates/Content. aspx? id=22823\&ssopc $=1$

5. Parvizi J, Gehrke T, Chen AF. Proceedings of the International Consensus on Periprosthetic Joint Infection. Bone Joint J 2013;95-B(11):1450-2. Crossref

6. Berbari EF, Hanssen AD, Duffy MC, Steckelberg JM, Ilstrup DM, Harmsen WS, Osmon DR. Risk factors for prosthetic joint infection: case-control study. Clin Infect Dis 1998;27(5):1247-54.

7. Saleh K, Olson M, Resig S, Bershadsky B, Kuskowski M, Gioe $\mathrm{T}$, Robinson $\mathrm{H}$, Schmidt R, McElfresh E. Predictors of wound infection in hip and knee joint replacement: results from a 20 year surveillance program. J Orthop Res 2002;20(3):506-15.

8. Jämsen E, Huhtala H, Puolakka T, Moilanen T. Risk factors for infection after knee arthroplasty. A register-based analysis of 43,149 cases. J Bone Joint Surg Am 2009;91(1):38-47. Crossref

9. Dowsey MM, Choong PF. Obesity is a major risk factor for prosthetic infection after primary hip arthroplasty. Clin Orthop Relat Res 2008;466(1):153-8. Crossref

10. Dowsey MM, Choong PF. Obese diabetic patients are at substantial risk for deep infection after primary TKA. Clin Orthop Relat Res 2009;467(6):1577-81. Crossref

11. Lübbeke A, Stern R, Garavaglia G, Zurcher L, Hoffmeyer $P$. Differences in outcomes of obese women and men undergoing primary total hip arthroplasty. Arthritis Rheum 2007; $57(2): 327-34$
12. Malinzak RA, Ritter MA, Berend ME, Meding JB, Olberding EM, Davis KE. Morbidly obese, diabetic, younger, and unilateral joint arthroplasty patients have elevated total joint arthroplasty infection rates. J Arthroplasty 2009;24(6 Suppl):84-8. Crossref

13. Galat DD, McGovern SC, Larson DR, Harrington JR, Hanssen AD, Clarke HD. Surgical treatment of early wound complications following primary total knee arthroplasty. J Bone Joint Surg Am 2009;91(1):48-54. Crossref

14. Ritter MA, Keating EM, Faris PM. Closed wound drainage in total hip or total knee replacement. A prospective, randomized study. J Bone Joint Surg Am 1994;76(1):35-8.

15. Murdoch DR, Roberts SA, Fowler Jr VG Jr, Shah MA, Taylor SL, Morris AJ, Corey GR. Infection of orthopedic prostheses after Staphylococcus aureus bacteremia. Clin Infect Dis 2001;32(4):647-9.

16. Murray RP, Bourne MH, Fitzgerald RH Jr. Metachronous infections in patients who have had more than one total joint arthroplasty. J Bone Joint Surg Am 1991;73(10):1469-74.

17. Khan LA, CowieJG, Ballantyne JA, Brenkel IJ. The complication rate and medium-term functional outcome after total hip replacement in smokers. Hip Int 2009;19(1):47-51.

18. Peersman G, Laskin R, Davis J, Peterson M. Infection in total knee replacement: a retrospective review of 6489 total knee replacements. Clin Orthop Relat Res 2001;(392):15-23.

19. Pulido L, Ghanem E, Joshi A, Purtill JJ, Parvizi J. Periprosthetic joint infection: the incidence, timing, and predisposing factors. Clin Orthop Relat Res 2008;466(7):1710-5. Crossref

20. Delank KS, Schmidt M, Michael JW, Dietlein M, Schicha H, Eysel P. The implications of 18F-FDG PET for the diagnosis of endoprosthetic loosening and infection in hip and knee arthroplasty: results from a prospective, blinded study. BMC Musculoskelet Disord 2006;7:20.

21. Della Valle CJ, Sporer SM, Jacobs JJ, Berger RA, Rosenberg AG, Paprosky WG. Preoperative testing for sepsis before revision total knee arthroplasty. J Arthroplasty 2007;22(6 Suppl 2):90-3.

22. Schinsky MF, Della Valle CJ, Sporer SM, Paprosky WG. Perioperative testing for joint infection in patients undergoing revision total hip arthroplasty. J Bone Joint Surg Am 2008;90(9):1869-75. Crossref

23. Ghanem E, Antoci V Jr, Pulido L, Joshi A, Hozack W, Parvizi $J$. The use of receiver operating characteristics analysis in determining erythrocyte sedimentation rate and C-reactive protein levels in diagnosing periprosthetic infection prior to revision total hip arthroplasty. Int J Infect Dis 2009;13(6):e444-9. Crossref

24. SpangehI MJ, Masri BA, O'Connell JX, Duncan CP. Prospective analysis of preoperative and intraoperative investigations for the diagnosis of infection at the sites of two hundred and two revision total hip arthroplasties. J Bone Joint Surg Am 1999;81(5):672-83.

25. Di Cesare PE, Chang E, Preston CF, Liu CJ. Serum interleukin-6 as a marker of periprosthetic infection following total hip and knee arthroplasty. J Bone Joint Surg Am 2005;87(9):1921-7.

26. Bottner $F$, Wegner A, Winkelmann W, Becker K, Erren $M$, Götze C. Interleukin-6, procalcitonin and TNF-alpha: markers of peri-prosthetic infection following total joint replacement. J Bone Joint Surg Br 2007;89(1):94-9.

27. Cipriano CA, Brown NM, Michael AM, Moric M, Sporer SM, Della Valle CJ. Serum and synovial fluid analysis for diagnosing chronic periprosthetic infection in patients with inflammatory arthritis. J Bone Joint Surg Am 2012;94(7):594-600. Crossref 
28. Della Valle C, Parvizi J, Bauer TW, Dicesare PE, Evans RP, Segreti J, Spangehl M, Watters WC 3rd, Keith M, Turkelson CM, Wies JL, Sluka P, Hitchcock K; American Academy of Orthopaedic Surgeons. Diagnosis of periprosthetic joint infections of the hip and knee. J Am Acad Orthop Surg 2010;18(12):760-70.

29. Trampuz A, Piper KE, Jacobson MJ, Hanssen AD, Unni KK, Osmon DR, Mandrekar JN, Cockerill FR, Steckelberg JM, Greenleaf JF, Patel R. Sonication of removed hip and knee prostheses for diagnosis of infection. $N$ Engl J Med 2007;357(7):654-63.

30. Fink B, Grossmann A, Fuerst M, Schäfer P, Frommelt L. Twostage cementless revision of infected hip endoprostheses. Clin Orthop Relat Res 2009;467(7):1848-58. Crossref

31. Barrack RL, Harris WH. The value of aspiration of the hip joint before revision total hip arthroplasty. J Bone Joint Surg Am 1993;75(1):66-76.

32. Glithero PR, Grigoris P, Harding LK, Hesslewood SR, McMinn DJ. White cell scans and infected joint replacements. Failure to detect chronic infection. J Bone Joint Surg $\mathrm{Br}$ 1993;75(3):371-4.

33. Williams J, Norman L, Stockley I. The value of hip aspiration versus tissue biopsy in diagnosing infection before exchange hip arthroplasty surgery. J Arthroplasty 2004;19(5):582-6.
34. Parvizi J, Jacovides C, Antoci V, Ghanem E. Diagnosis of periprosthetic joint infection: the utility of a simple yet unappreciated enzyme. J Bone Joint Surg Am 2011;93(24):2242-8. Crossref

35. Wetters NG, Berend KR, Lombardi AV, Morris MJ, Tucker TL, Della Valle CJ. Leukocyte esterase reagent strips for the rapid diagnosis of periprosthetic joint infection. J Arthroplasty 2012;27(8 Suppl):8-11. Crossref

36. Bingham J, Clarke $H$, Spangehl $M$, Schwartz A, Beauchamp C, Goldberg B. The alpha defensin-1 biomarker assay can be used to evaluate the potentially infected total joint arthroplasty. Clin Orthop Relat Res 2014;472(12):4006-9. Crossref

37. Deirmengian C, Kardos K, Kilmartin P, Cameron A, Schiller K, Parvizi J. Diagnosing periprosthetic joint infection: has the era of the biomarker arrived? Clin Orthop Relat Res 2014;472(11):3254-62. Crossref

38. Springer BD, Parvizi J, editors. Periprosthetic Joint Infection of the Hip and Knee. New York: Springer-Verlag; 2013. p. xvii. 